\title{
Glucosamine-sulfate on fracture healing
}

\author{
Glukozamin sülfatın kırık iyileşmesine etkisi
}

\author{
Akın UĞRAŞ, ${ }^{1 \dagger}$ Elif GÜZEL, ${ }^{2}$ Petek KORKUSUZ, ${ }^{3}$ İbrahim KAYA, ${ }^{1}$ \\ Fatih DİKİCI, ${ }^{4}$ Emrah DEMIRBAŞ, ${ }^{1}$ Ercan ÇETINUS ${ }^{1}$
}

\section{BACKGROUND}

The aim of this study is to determine whether glucosaminesulfate has any effects on bone-healing.

\section{METHODS}

A unilateral fracture was created in the tibia of sixty-one female rats. Rats were given no drug or $230 \mathrm{mg} / \mathrm{kg}$ glucosamine-sulfate daily. Fractures were analyzed during the first, second and fourth weeks after creation of fracture. Quantitative measurement for new bone formation and osteoblast lining were determined histologically. Semiquantitative score for fracture healing was used for histomorphometric analyses. Bridging bone formation was assessed radiographically.

\section{RESULTS}

New bone formation and osteoblast lining were significantly higher in glucosamine-treated group at week 1. Surrounding connective tissue was more cellular and vascular, and the newly formed bone trabecules were present in greater amounts in glucosamine-treated group, compared to control group at week 1 and 4. But radiologically, the control group had better scores than that of the glucosamine-treated group at week 4 .

\section{CONCLUSION}

These data demonstrate that daily glucosamine-sulfate administration accelerates early phase of fracture repair in the rat tibia, with increased new bone formation and osteoblast lining histologically, but radiologic bone union is not favored on radiographs.

Key Words: Bone; fracture healing; glucosamine; osteoblast.

\section{$\boldsymbol{A M A C}$}

$\mathrm{Bu}$ çalışmanın amacı kıkırdak glukozaminin kırık iyileşmesi üzerinde etkisi olup olmadığının araştırılmasıdır.

\section{GEREÇ VE YÖNTEM}

Altmış bir dişi şıçan tibiasında tek taraflı kırık oluşturuldu. Sıçanlara ya $230 \mathrm{mg} / \mathrm{kg}$ glukozamin sülfat verildi ya da ilaç verilmedi. Kırıklar, kırık oluşumundan sonra birinci, ikinci ve dördüncü haftalarda incelendi. Yeni kemik oluşum miktarı ve osteoblast sayısı histolojik olarak ölçüldü. Histomorfometrik analiz için kırık iyileşmesi semikantitatif olarak skorlandı. Radyografik olarak kemik köprü oluşumu değerlendirildi.

\section{BULGULAR}

Glukozamin verilen grupta yeni kemik oluşumu ve osteoblast sayısı 1. haftada anlamlı derecede yüksekti. 1. ve 4. haftalarda kontrol grubuna göre, glukozamin verilen grupta çevre bağ dokusu hücre sayısı bakımından zengin, daha vasküler ve yeni oluşan kemik trabekülleri daha fazla sayıdaydı. Fakat radyolojik olarak 4. haftada kontrol grubu, glukozamin verilen gruptan daha iyi skorlar ald.

\section{SONUÇ}

$\mathrm{Bu}$ veriler günlük glukozamin verilmesinin sıçan tibiasında kırık iyileşmesinin erken fazını, artmış yeni kemik oluşumu ve osteoblast sayısı ile histolojik olarak hızlandırdığı, fakat radyolojik olarak aynı etkinin görülmediğini göstermektedir.

Anahtar Sözcükler: Kemik; kırık iyileşmesi; glukozamin; osteoblast.

\footnotetext{
${ }^{1}$ Department of Orthopedics and Traumatology, Haseki Training and Research Hospital, Istanbul; ${ }^{2}$ Department of Histology and Embryology, Istanbul University, Cerrahpasa Faculty of Medicine, Istanbul; ${ }^{3}$ Department of Histology and Embryology, Hacettepe University, Faculty of Medicine, Ankara; ${ }^{4}$ Department of Orthopedics and Traumatology, Istanbul University, Istanbul Faculty of Medicine, Istanbul, Turkey.

$†$ Current affiliation: Department of Orthopedics and Traumatology, Istanbul Medipol University, Faculty of Medicine, Istanbul.
}
${ }^{1}$ Haseki Eğitim ve Araştırma Hastanesi, Ortopedi ve Travmatoloji Kliniği, İstanbul; ${ }^{2}$ İstanbul Üniversitesi Cerrahpaşa Tıp Fakültesi,
Histoloji ve Embriyoloji Anabilim Dalı, İstanbul; ${ }^{3}$ Hacettepe Üniversitesi T1p Fakültesi, Histoloji ve Embriyoloji Anabilim Dalı, Ankara;
${ }^{4}$ İstanbul Üniversitesi İstanbul Tıp Fakültesi, Ortopedi ve Travmatoloji Anabilim Dalı, İstanbul.
†Şimdiki Kurumu: İstanbul Medipol Üniversitesi Tıp Fakültesi, Ortopedi ve Travmatoloji Anabilim Dalı, İstanbul.


Glucosamine has been shown to have a number of favorable effects on cartilage metabolism in vitro, including a reduction in articular cartilage breakdown and stimulation of synthesis of matrix components by condrocytes. ${ }^{[1]}$ Administration of glucosamine normalizes cartilage metabolism, by inhibiting degradation and stimulating the synthesis of proteoglycans, and restoring the articular functions. ${ }^{[2]}$

However, the effect of glucosamine on bone metabolism has not been investigated before. We hypothesized that glucosamine could be a therapeutic agent for the treatment of intraarticular fractures. The aim of this study is to determine whether glucosamine-sulfate has any effects on bone-healing. Glucosamine exists in several forms, usually as glucosamine-sulfate and glucosamine hydrochloride. Sulfate form has been used in most experimental studies. ${ }^{[3]}$ We investigate the role of glucosamine-sulfate on fracture healing.

\section{MATERIALS AND METHODS}

The study was conducted in accordance with principles and procedures approved by Istanbul University, the Local Ethics Committee on animal experimentation. Sixty-one female Wistar rats were used for this study. Only the sixth group had 11 rats (Glucosaminetreated group). Two or three rats were housed in each cage with a $12 \mathrm{~h}-12 \mathrm{~h}$ light-dark cycle and controlled temperature of $24 \pm 3{ }^{\circ} \mathrm{C}$ with humidity of $55 \pm 15 \%$. They were fed with water and standard rat chow ad libitum. Rats were 6 weeks old and weighing 200-250 g. Three groups of rats received $230 \mathrm{mg} / \mathrm{kg}$ glucosamine-sulfate (Abdi Ibrahim, Dona, Turkey) intraperitoneally (IP), daily. The other three groups of rats served as a control group. Dose selection was based on preliminary studies. ${ }^{[1,4]}$

Rats were anesthetized with ketamine $(0.25$ $\mathrm{mg} / 100 \mathrm{~g})$ and xylazine $(10 \mathrm{mg} / 100 \mathrm{~g})$ IP. Once the animal was sedated, the skin overlying knee was shaved. A prophylactic dose of 60.000 IU of procain penicillin was administered intramuscularly. The skin overlying left knee was incised. Anterior tibial cortex was cut with sagittal saw and posterior tibial cortex was broken. A $0.25 \mathrm{~mm}$ metal pin was inserted in to the medullary canal of the tibia. The incision was closed. ${ }^{[5-7]}$ The rats were allowed to recover and were permitted to eat and walk ad libitum. Subsets of animals from each glucosamine-treated and control group were sacrificed at first, second, and fourth weeks postoperatively by administering a lethal dose of sodium pentobarbital IP.

Radiographs were made of all tibia to determine whether administration of glucosamine-sulfate resulted in radiographic evidence of delayed healing. Bone formation was scored on a 6-point scale as follows: 0 , no formation of bone; 1 , formation of less than $25 \%$ of bone; 2, formation of more than $25 \%$ of bone; 3 , formation of more than $50 \%$ of bone; 4 , formation of more than $75 \%$ of bone; and 5 , formation of $100 \%$ of bone. ${ }^{[8]}$ The radiographs were blindly scored by three orthopedic surgeons for the presence of calcified fracture callus and evidence of bone union. The final score was the mean of all three scores.

Bones were fixed in $10 \%$ neutral buffered formalin at room temperature. All specimens were decalcified in De Castro solution (chloral hydrate, nitric acid, distilled water) and embedded in paraffin. Three to five micrometer thick sections were stained with haematoxylin \& eosin (HE), and Masson's trichrome (MT).

\section{Quantitative measurement for new bone formation and osteoblast lining at fracture site}

MT produces high contrast images with red (bone), green (osteoid-cartilage), and purple (cell cytoplasm). Photomictographs of each fracture area were generated by a light microscope (Leica DMR) with attached computerized digital camera (Model DFC 480, Leica Westlar Germany). The entire fracture area was visible at the lowest magnification. Bright-field images were captured and analyzed quantitatively by image processing program (Qwin Plus, Leica Inc. Westlar Germany). The number of pixels corresponding to new trabecular bone area in each image was quantified, divided by the total number of pixels corresponding to total fracture area, and converted to $\mu \mathrm{m}^{2}$ in each specimen. Osteoblasts were quantified based on their morphology on HE stained sections for length of their linear apposition along osteoid-new bone surfaces relative to total new bone-osteoid surface length for three randomly selected high power fields $(200 \mathrm{x})$ and are reported as a fraction (\%) average for each sample. ${ }^{[9]}$

\section{Semiquantitative scoring for fracture healing}

A total fracture healing score was given to each specimen regarding the callus formation, bone union, marrow changes, and cortex remodeling. ${ }^{[10]}$ Regarding callus formation, (3) was given for presence of full callus formation across the defect, (2) for presence of moderate callus formation, (1) for presence of mild callus formation, and ( 0 ) for no callus formation. Bone union was scored as (3) for full bone bridge (union), (2) for moderate bridge $(>50 \%)$, (1) for mild bridge $(<50 \%)$, and $(0)$ for the lack of new bone in the fracture line (nonunion). Regarding marrow changes, (4) was given for the presence of adult type fatty marrow, (3) for $2 / 3$ of marrow replaced by new tissue, (2) for $1 / 3$ of marrow replaced by new tissue, (1) for the presence of fibrous tissue, and (0) for the red tissue. Regarding cortex remodeling, (2) was given for the presence of full remodeling cortex, (1) for intramedullary canal, and ( 0 ) for the lack of cortical remodeling. 

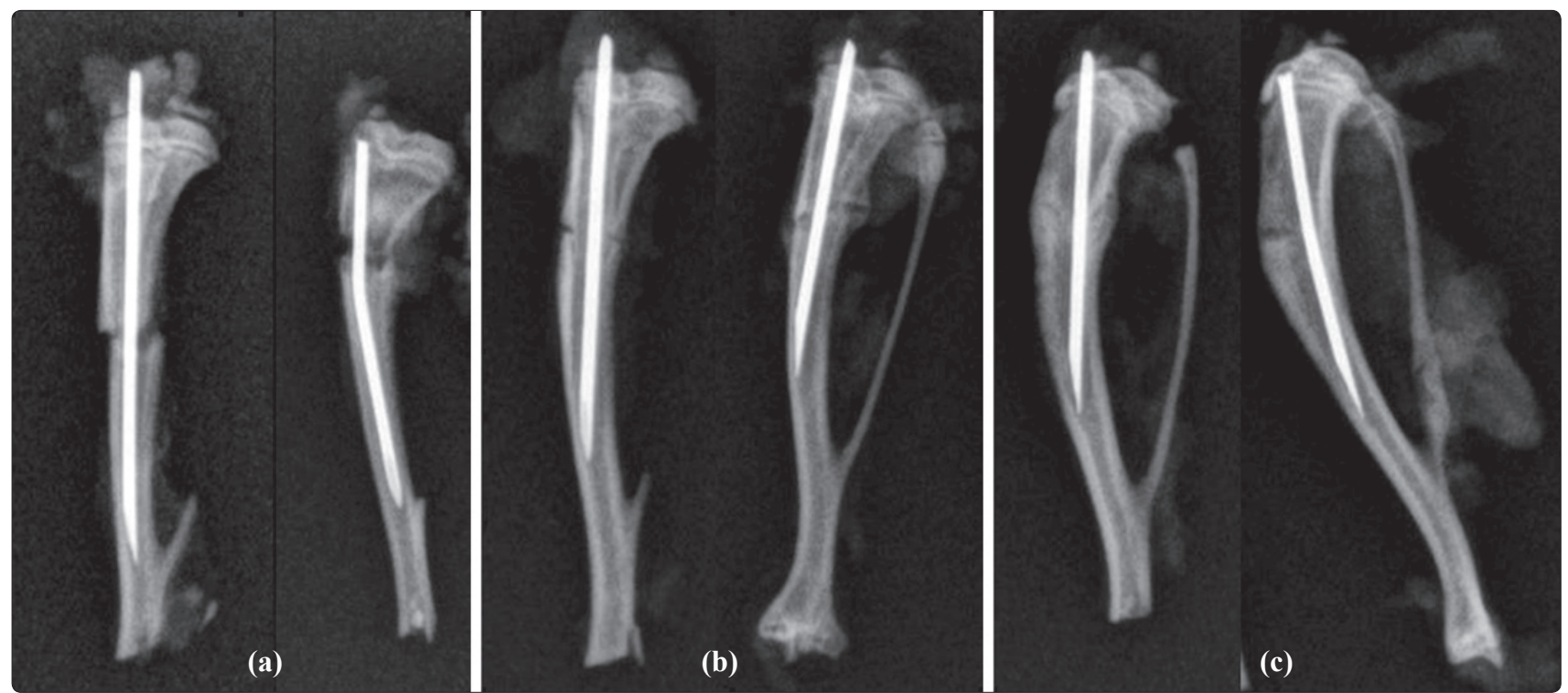

Fig. 1. Radiographs of isolated tibia at (a) one, (b) two, and (c) six weeks after the fracture. Left: Glucosamine-treated group, Right: Control group.

${ }^{[10]}$ Fracture healing score is the sum of callus formation score, bone union score, marrow changes score, and cortex remodeling score.

\section{Statistical analysis}

Independent variables were the division of groups based upon glucosamine-sulfate administration, and the dependent variables were the histology and radiology parameters. The normality of distribution and the homogeneity of variances of the sample were established using the Shapiro-Wilk test. All week 1 parameters, osteoblast lining parameter of week 2, and osteoblast lining and bone healing parameters of week 4 were analyzed by parametric test one way ANOVA. All other parameters were analyzed by nonparametric tests. Kruskal-Wallis was used for multiple comparison and Mann-Whitney $U$ as post-hoc test with
Bonferroni correction. Correlation between the histologic and radiologic measurements were assessed using Spearman test. Radiologic scoring was performed by blind independent investigators $(n=3)$. The intraclass (reliability) correlation coefficient was calculated $(r=0.80)$. Then the mean of calculated radiologic scores was included in parametric and nonparametric analyses. Descriptive statistical values were expressed as median, minimum, and maximum. The difference was considered significant if $\mathrm{p}<0.05$.

\section{RESULTS}

The radiographic appearance of films suggested normal fracture healing. There was neither ectopic calcification nor unusual (e.g., over-abundant) callus formation. Complete bone healing was observed in both groups. Radiologic scores did not show any significant

Table 1. The data of variables belonging to different groups are given as mean, standart deviation and $\mathrm{p}$ values

\begin{tabular}{llllll}
\hline Sacrification time & Groups & $\begin{array}{l}\text { Radiologic } \\
\text { score }\end{array}$ & $\begin{array}{l}\text { New bone per fracture } \\
\text { line ratio }\left(\mu \mathrm{m}^{2}\right)\end{array}$ & $\begin{array}{l}\text { Osteoblast } \\
\text { lining }(\%)\end{array}$ & $\begin{array}{l}\text { Fracture } \\
\text { healing score }\end{array}$ \\
\hline First week & Glc & $2.85 \pm 0.89$ & $0.22 \pm 0.07$ & $30.36 \pm 8.92$ & $3.9 \pm 1.28$ \\
& Control & $3.08 \pm 0.69$ & $0.09 \pm 0.03$ & $19.5 \pm 6.84$ & $3 \pm 0.94$ \\
& $p$ & 0.405 & $0.000^{*}$ & $0.007^{*}$ & 0.101 \\
& & & & & \\
Second week & Glc & $3.8 \pm 1.12$ & $0.29 \pm 0.07$ & $35.29 \pm 11.25$ & $6.6 \pm 1.26$ \\
& Control & $3.2 \pm 0.61$ & $0.23 \pm 0.08$ & $35.6 \pm 12.38$ & $6.5 \pm 1.35$ \\
& $p$ & 0.057 & 0.226 & 0.820 & 0.846 \\
Fourth week & & & & & \\
& Glc & $4.25 \pm 0.59$ & $0.92 \pm 0.07$ & $55.5 \pm 17.85$ & $10.36 \pm 1.12$ \\
& Control & $4.85 \pm 0.36$ & $0.93 \pm 0.06$ & $59.56 \pm 17.02$ & $10 \pm 1.41$ \\
& $p$ & $0.036^{*}$ & 0.809 & 0.654 & 0.705 \\
\hline
\end{tabular}

Glc: Glucosamine-treated group; * $\mathrm{p}<0.005$. 
difference between groups at week 1 and week 2. Radiologically, the control group received significantly better scores than the glucosamine-treated group at week $4(\mathrm{p}=0.036)$ (Fig. 1, Table 1).

New bone per fracture line ratio was significantly higher in glucosamine-treated group comparing to that of control group at week $1(p=0.000)$. New bone trabecules lined by active bone-forming cells (osteoblasts) were higher in the glucosamine-treated group in comparison to control on day $7(\mathrm{p}=0.007)$ (Fig. 2, Table 1). Histologic scores did not show any significant difference between groups at week 2 .

Histomorphologically, a highly vascular and cellular connective tissue callus initiated intramembranous and/or endochondral bone formation at the fracture area in both groups. Surrounding connective tissue was more cellular and vascular and the newly formed bone trabecules were more numerous in the glucosamine-treated group, comparing to control at week 1 and 4 (Fig. 2, Table 1).

The radiologic and histologic bone healing parameters generally increased over time ( 1 to 2,2 to 4 , and 1 to 4 weeks) in control and glucosamine-treated groups $(\mathrm{p} \leq 0.05)$. This data demonstrates that a healthy healing process occurred in both groups.
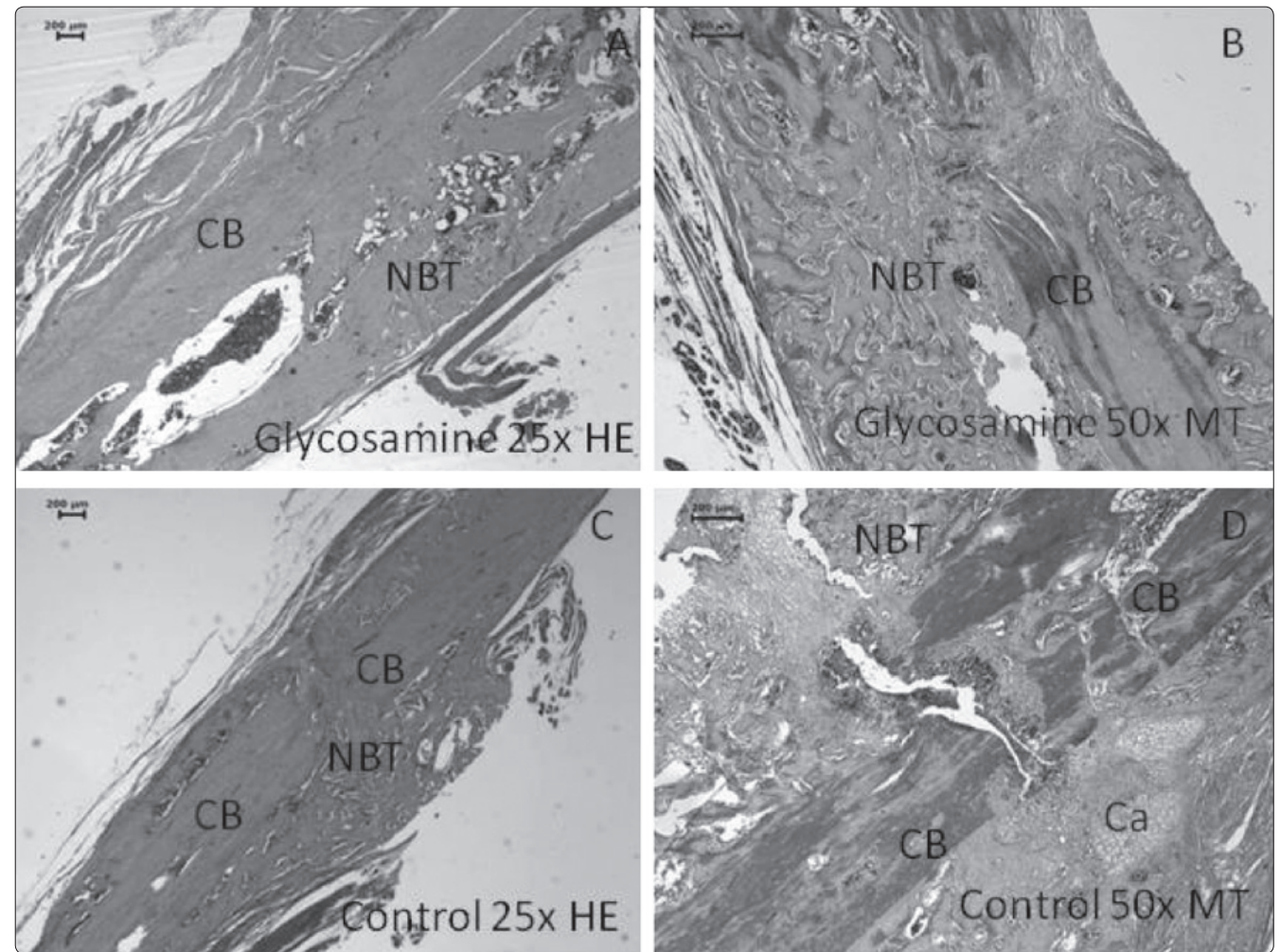

Fig. 2. Fracture line consists of a fibrous, cartilaginous $(\mathrm{Ca})$ and bony callus (NBT: New bone trabecules in green) at 1 week; in both glucosamine and the control groups. Note the high amount of new bone trabecules in B with glucosamine when compared to control (D). Cartilage islands are obvious in D. CB: Cortical bone; HE: Haematoxylin eosin, MT: Masson's trichrome.

\section{DISCUSSION}

According to this data, glucosamine sulphate increased new bone formation, osteoblastic cell lining, bone trabecules, and cellularity and vascularity of the cartilage matrix. New bone formation was accelerated in the glucosamine-treated group at week 1, whereas radiographic bone healing was diminished at week 4 .

Fracture repair is a complex process that involves mesenchymal and/or surface osteoblasts and signaling molecules including proinflammatory cytokines, transforming growth factor-beta (TGF- $\beta$ ) superfamily members and angiogenic factors. ${ }^{[11,12]}$ The repair is initiated by an immediate inflammatory response that leads to the recruitment of mesenchymal stem cells and subsequent differentiation into mesenchymal osteoblasts that produce cartilage matrix. ${ }^{[12]}$ According to this data, glucosamine-sulfate affects the first stages of bone repair and increases osteoblastic cell lining, bone trabecules, and cellularity and vascularity of the cartilage matrix.

Kim and collaborators ${ }^{[13]}$ demonstrated that glucosamine sulfate can increase Alchalen phospatase activity, collagen synthesis, osteocalcin secretion, and mineralization in osteoblastic cells in vitro. Glucosamine sulfate exerts a stimulatory effect on differentiation in 
osteoblast-like MG-63 cells in vitro. ${ }^{[13]}$ We think that the probable mechanism of glucosamine sulphate's effect on bone healing is through the stimulation of osteoblastic cells.

We did not observe the same effect at the end of the healing process. In comparison to the glucosaminetreated group, radiologic bone union was not as evident as in the control group. However, the histologic parameters of bone union did not differ between the two groups at the fourth week. We did not perform mechanical testing to accurately interpret the results. However, bone strength is mainly characterized by architectural structure, the mineral content of bone, extracellular matrix properties, and cellular biomechanics and these are accurately assessed by histological analysis. ${ }^{[14]}$

The major limitation of this study is the absence of a dose-response study of glucosamine-sulfate. However, this is the first study, to our knowledge, evaluating the effects of glucosamine-sulfate on fracture healing. Additional studies are necessary to determine the effects of glucosamine on fracture-healing.

Given the central role of glucosamine in cartilage metabolism, it is likely to have a profound influence on bone metabolism. In summary, daily glucosamine sulfate administration following fracture increased bone formation in the rat tibia, with increased new bone formation and osteoblast lining histologically. However, the presence of radiologic bone union was not demonstrated by radiographs in the treatment group.

Conflict-of-interest issues regarding the authorship or article: None declared.

\section{REFERENCES}

1. Maganhin CC, Correa O, Regina Ct G, Simões R, Baracat EC, Soares-Jr JM. Effects of glucosamine on the tibial epiphyseal disk of ovariectomized rats: morphologic and morphometric analysis. Clinics (Sao Paulo) 2007;62:607-12.

2. Hua J, Suguro S, Hirano S, Sakamoto K, Nagaoka I. Preventive actions of a high dose of glucosamine on adjuvant arthritis in rats. Inflamm Res 2005;54:127-32.
3. Mobasheri A, Vannucci SJ, Bondy CA, Carter SD, Innes JF, Arteaga MF, et al. Glucose transport and metabolism in chondrocytes: a key to understanding chondrogenesis, skeletal development and cartilage degradation in osteoarthritis. Histol Histopathol 2002;17:1239-67.

4. Rezende MU, Gurgel HM, Vilaça Junior PR, Kuroba RK, Lopes AS, Phillipi RZ, et al. Diacerhein versus glucosamine in a rat model of osteoarthritis. Clinics (Sao Paulo) 2006;61:461-6.

5. Hollinger JO, Onikepe AO, MacKrell J, Einhorn T, Bradica $\mathrm{G}$, Lynch S, et al. Accelerated fracture healing in the geriatric, osteoporotic rat with recombinant human platelet-derived growth factor-BB and an injectable beta-tricalcium hosphate/ collagen matrix. J Orthop Res 2008;26:83-90.

6. Miles JD, Weinhold P, Brimmo O, Dahners L. Rat tibial osteotomy model providing a range of normal to impaired healing. J Orthop Res 2011;29:109-15.

7. Gardner MJ, van der Meulen MC, Carson J, Zelken J, Ricciardi BF, Wright TM, et al. Role of parathyroid hormone in the mechanosensitivity of fracture healing. J Orthop Res 2007;25:1474-80.

8. Yasko AW, Lane JM, Fellinger EJ, Rosen V, Wozney JM, Wang EA. The healing of segmental bone efects, induced by combinant human bone morphogenetic protein (rhBMP-2). A radiographic, histological, and biomechanical study in rats. J Bone Joint Surg [Am] 1992;74:659-70.

9. Lu M., Rabie ABM. Quantitative assessment of early healing of intramembranous and endochondral autogenous bone grafts using micro-computed tomography and Qwin image analyzer. Int J Oral Maxillofac Surg 2004;33:369-37.

10. An Y H, Friedman RJ. Animal models in orthopedic research. CRC Press USA: 1999. p. 209.

11. Tat SK, Pelletier JP, Vergés J, Lajeunesse D, Montell E, Fah$\mathrm{mi} \mathrm{H}$, et al. Chondroitin and glucosamine sulfate in combination decrease the pro-resorptive properties of human osteoarthritis subchondral bone osteoblasts: a basic science study. Arthritis Res Ther 2007;9:R117.

12. Wang SX, Laverty S, Dumitriu M, Plaas A, Grynpas MD. The effects of glucosamine hydrochloride on subchondral bone changes in an animal model of osteoarthritis. Arthritis Rheum 2007;56:1537-48.

13. Kim MM, Mendis E, Rajapakse N, Kim SK. Glucosamine sulfate promotes osteoblastic differentiation of MG-63 cells via anti-inflammatory effect. Bioorg Med Chem Lett 2007; 17:1938-42.

14. Kreider JM, Goldstein SA. Trabecular bone mechanical properties in patients with fragility fractures. Clin Orthop Relat Res 2009;467:1955-63. 